\title{
Screening of Antimicrobial Spectrum of Brevibacillus sp. Isolated from Dairy Environment
}

\author{
Sandeep Kumar ${ }^{1 *}$, Ebenezer Jeyakymar ${ }^{2}$, Rubina Lawrence ${ }^{2}$, Utkarsh Singh Rathore ${ }^{1}$ \\ and Monika Mishra ${ }^{1}$
}

${ }^{1}$ Division of Crop Protection, Indian Institute of Pulses Research, Kalyanpur, Kanpur, UP (East), India

${ }^{2}$ Department of Industrial Microbiology, Sam Higginbottom University of Agriculture, Technology and Sciences, Allahabad, India

*Corresponding author

\begin{abstract}
A B S T R A C T
Key words

Brevibacillus brevis, Brevicin, Bacteriocin,

Antagonistic activity,

Tyrosine agar

Article Info

Accepted:

10 April 2018

Available Online:

10 May 2018

Bacteriocins and Bacteriocin like Inhibitory Substance (BLIS) are ribosomal products exhibiting antimicrobial activity. The present study aimed to screen for production of antimicrobial agents from soil bacteria of dairy environment. Borer was used to dig soil and collected in sterile plastic bags. Isolation was done on tyrosine agar. To exclude non spore formers the soil suspension, was heated at $80^{\circ} \mathrm{C}$. The bacterial isolates were identified underpinning biochemical and carbohydrate utilization tests and screened for their antibacterial activity against methicillin resistant $S$. aureus and E. coli by agar well diffusion method. Among forty nine isolates three isolates were identified as Brevibacillus brevis. Screening of crude brevicin obtained from cell free broth inoculated with $B$. brevis exhibited a strong antagonistic activity against $S$. aureus but no zone of inhibition was recorded against $E$. coli. The spore forming bacterium, B. brevis produced narrow spectrum antibacterial agent. Strains of Brevibacillus are potent source of bacteriocins and these antimicrobial peptides can be used as an effective therapeutic agent in pharmaceuticals as well as can also be used as food preservatives in canned or packed food and dairy products, controlling pathogens with natural products instead of synthetic ones.
\end{abstract}

\section{Introduction}

Bacteria and their products have been proved to be beneficial as well as harmful in different sectors such as food and dairy, pharmaceutical, etc. Spoilage of food materials even after packaging is of great concern for industries. However, advancement in technology has ameliorated the losses.
Fulfilling the consumer demands of ready to eat materials are on hike, placing a challenge for industries to provide quality food. Microbes are ubiquitous and very much adaptive and evolve new strategies to survive, resulting in altered food safety hazards, WHO food strategic planning meeting have noticeably have shown their concern on the issue (Food safety strategic planning meeting, 
2001). Similarly, rapid spread of antibiotic resistant pathogens due to institutional abuse of antibiotics is an alarm to find alternative methods of combating infections. A biological tool of natural origin, which can be used in both the sectors, is needed. Bacteriocins are ribosomally synthesized peptides produced by bacteria itself, with ability to kill or inhibit microorganisms usually associated, but not always, to the producer strain (Klaenhammer, 1988). Recent studies have demonstrated the potential use of bacteriocins as natural preservatives and its therapeutic applications against bacteria with Multiple Drug Resistance (MDR) (Singh et al., 2012; Galvez et al., 2007; Bizani and Brandelli, 2002). Based on their molecular weight bacteriocins have been characterized into three classes; Nisin, one of the broadly studied bacteriocin from $\mathrm{LAB}$ fall into Lantibiotics or class I bacteriocin due to its small size and granted Generally Recognized as Safe (GRAS) by United States Food and Drug Administration (USFDA) (Galvez et al., 2007; Klaenhammer, 1993; Maisnier-Patin, 1992). Among bacteriocin producing bacteria, the genus Bacillus is one of the diverse group reported to produce a variety of antimicrobial peptides or BLIS, such as, subtilin from B. subtilis, cerein from $B$. cereus, megacin from $B$. megaterium, lichenin from $B$. licheniformis, $B$. stearothermophilus, etc. (Pattnaik et al., 2005; Hyung et al., 2001).

Bacillus brevis, primarily as soil bacterium was reclassified into the genera Brevibacillus in 1996 (Shida et al., 1996) and have been reported for production of peptide antibiotics Gramicidin and Tyrocidine. Different strains of $B$. brevis have shown antagonistic effect on various gram positive and gram negative organisms, the bacterium have also reported for extending the shelf life of curd (Anja et al., 2014; Appaiah et al., 2012; Gillor et al., 2008). In consideration of the above background a strain of Brevibacillus brevis was isolated from soil samples collected from dairy environment with help of surface sterilized borer.

\section{Materials and Methods}

The research was conducted in Sam Higginbottom University of Agriculture, Technology and Sciences, Allahabad. Soil samples from SHUATS dairy environment for isolation of bacteriocin producing bacteria was collected and stored in sterilized zipper plastic bags. All experiments i.e. isolation, identification and screening of bacteriocin production was conducted in laboratory of Department of Industrial Microbiology, SHUATS.

\section{Isolation and identification of bacterial strain}

A total of one hundred soil samples were collected from a depth of $5-15 \mathrm{~cm}$ at different sites. One gram of each soil sample was transferred to $10 \mathrm{ml}$ of sterilized Ringer's solution aseptically and serially diluted to $10^{-6}$. Each of the dilution tube was heated at $80{ }^{\circ} \mathrm{C}$ in a preheated water bath for $20 \mathrm{~min}$ to exclude non-spore formers. After cooling to room temperature, $1 \mathrm{ml}$ of suspension from each tube was put onto the petriplates and sterilized molten tyrosine agar was poured over the suspension. As soon as the agar got solidified the plated were flipped upside down and incubated at $37{ }^{\circ} \mathrm{C}$. Observations were recorded after 48 to $72 \mathrm{hr}$; colonies with dark pigment around the colonies were quarantined on nutrient agar slants after purification with quadrant streaking. To identify the bacterial strain, isolates were carried through series of, cultural, morphological and physiological tests, including Grams reaction, spore staining, growth under various conditions, carbohydrate utilization, etc. according to "Bergey's Manual of Systematic Bacteriology" (Table $1)$. 


\section{Bacteriocin production}

Muller Hinton Broth (MHB) (Hi-media) with $\mathrm{pH}$ at neutrality was used as production medium, $25 \mathrm{ml}$ broth was prepared in $50 \mathrm{ml}$ Erlenmeyer flasks and sterilized at $121{ }^{\circ} \mathrm{C}$ for $15 \mathrm{~min}$, selected isolates were inoculated as soon as the broth came to room temperature followed by incubation in shaking incubator at $35^{\circ} \mathrm{C}$ with $100 \mathrm{rpm}$ for 24 and $48 \mathrm{hr}$.

\section{Detection of antimicrobial activity}

A cell free suspension (CFS) was prepared by centrifuging the MHB, at $4500 \mathrm{x}$ g for $20 \mathrm{~min}$ and stored at $4{ }^{\circ} \mathrm{C}$. The antimicrobial activity determined by agar well diffusion method on Muller Hinton Agar (MHA) (Hi-media) against indicator organisms i.e. E. coli (MCCB 0017) and methicillin resistant $S$. aureus (MCCB 0139) provided by Microbial Collection Culture Bank, Department of Industrial Microbiology, SHUATS. A 12-18 $\mathrm{hr}$ old culture broth of indicator organisms $\left(10^{7} \mathrm{CFUml}^{-1}\right)$ were swabbed on the MHA plates and $5 \mathrm{~mm}$ wells were cut out, an aliquot of $50 \mu \mathrm{l}$ of CFS was filled in the wells followed by incubation at $37{ }^{\circ} \mathrm{C}$. The antagonistic activity in Arbitrary unit $/ \mathrm{ml}$ $\left(\mathrm{AUml}^{-1}\right.$ ) was calculated (Bhaskar et al., 2007) as a measure of bacteriocin production.

\section{Diameter of zone of clearance (mm) X 1000 \\ $\mathrm{AUml}^{-1}=\quad$ Volume of CFS in the well $(\mu \mathrm{ll})$}

\section{Results and Discussion}

Isolation and Identification of bacterial strain

49 isolates were quarantined from hundred soil samples collected form diary environment, on the basis of the method mentioned by Edwards and Seddon (2000). Among these isolates three were viz. 18, 54 and 55 identified as Brevibacillus brevis (6\%) and $20 \%$ as B. licheniformis, $18 \%$ as $B$. megaterium, $6 \%$ as $B$. pumilus, $4 \%$ as $B$. coagulans based on morphological and biochemical characteristics enlisted in Table 1.

The organisms were found motile, spore bearer, gram positive and strictly aerobic.

The carbohydrate profile (Table 2) of bacteria under investigation depicts that it could utilize glucose, fructose, glycerol, mannitol, sucrose, trehalose, maltose, ribose and melezitose with weak production of acid and little or no gas production; but could not utilize xylose, sorbitol, salicin, rhamnose, raffinose, melebiose, mannose, lactose, inositol and arabinose. Similar results have been reported by Ghadbane et al., (2013).

\section{Detection of antimicrobial activity}

All three isolates were examined for their antibacterial activity against $E$. coli and methicillin resistant strain of $S$. aureus. Crude brevicin from isolate no. 18 displayed largest zone of inhibition among all the three isolates against $S$. aureus.

The crude brevicin obtained after $24 \mathrm{hr}$ of incubation displayed higher activity than that of $48 \mathrm{hr}$ incubation time. The results are summarized in the (Table 3). On calculating the effectiveness in terms of arbitrary unit per milliliter $\left(\mathrm{AUmL}^{-1}\right)$ (Bhaskar et al., 2007; Bhuvaneswari et al., 2015) the activity of crude brevicin was found with upper limit of $440 \mathrm{AUmL}^{-1}$ for isolate no. 18 against $S$. aureus followed by $360 \mathrm{AUmL}^{-1}$ and 210 $\mathrm{AUmL}^{-1}$ for isolate no. 54 and 55 respectively (Fig. 1). In contrast, no activity was observed against E. coli (Fig. 2).

The genus Brevibacillus is mainly a soil organism, found readily in soil with high humus (Elo et al., 2000). 
Table.1 Morphological and biochemical characteristic of isolated no. 18

\begin{tabular}{|c|c|c|c|}
\hline Characteristics studied & 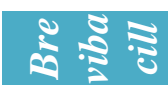 & $\leftrightarrow \stackrel{\infty}{\infty} \leqslant$ & $\leftrightarrow: \frac{3}{3}$ \\
\hline Gram reaction & + ve & + ve & + ve \\
\hline Size (in $\mu \mathrm{m}$ ) & $3.0-4.3$ & $2.0-4.6$ & $1.6-2.8$ \\
\hline Endospore & + ve & + ve & + ve \\
\hline Growth at $45^{\circ} \mathrm{C}$ & + ve & + ve & +ve \\
\hline Growth at $65^{\circ} \mathrm{C}$ & - ve & -ve & -ve \\
\hline Growth at pH 5.7 & + ve & + ve & + ve \\
\hline Growth in $7 \% \mathrm{NaCl}$ & + ve & + ve & +ve \\
\hline Growth in lysozyme & + ve & + ve & +ve \\
\hline Growth in anaerobic medium & - ve & -ve & + ve \\
\hline Motility & + ve & + ve & + ve \\
\hline Hemolysis & - ve & + ve & +ve \\
\hline Hydrolysis of esculin & + ve & -ve & -ve \\
\hline Hydrolysis of gelatin & + ve & + ve & \pm ve \\
\hline Tyrosine degradation & - ve & + ve & -ve \\
\hline Hydrolysis of urea & + ve & -ve & -ve \\
\hline Catalase & + ve & + ve & + ve \\
\hline Oxidase & + ve & + ve & + ve \\
\hline Lysine decarboxylase (LDC) & - ve & -ve & -ve \\
\hline Ornithine decarboxylase (ODC) & - ve & -ve & -ve \\
\hline Indole production & - ve & -ve & -ve \\
\hline Voges-Proskauer & -ve & -ve & -ve \\
\hline Nitrate reduction & + ve & + ve & + ve \\
\hline Egg yolk reaction & - ve & + ve & +ve \\
\hline Citrate utilization & + ve & + ve & -ve \\
\hline
\end{tabular}


Table.2 Fermentation profile of different carbohydrates by isolate no. 18

\begin{tabular}{|l|l|l|l|l|}
\hline Carbohydrate & & & \\
& & &
\end{tabular}

Table.3 Inhibitory effect of crude brevicin from different isolates against indicator organisms after 24 and $48 \mathrm{hrs}$ respectively

\begin{tabular}{|c|c|c|c|}
\hline & \multicolumn{3}{|c|}{ zone of inhibition } \\
\hline & $\begin{array}{c}\text { S. aureus MCCB } 0139 \text { (in } \\
\text { mm) }\end{array}$ & $\begin{array}{c}\text { E. coli MCCB } 0017 \text { (in } \\
\text { mm) }\end{array}$ \\
\hline $\begin{array}{c}\text { CFS after } \mathbf{2 4} \\
\text { hr }\end{array}$ & $\begin{array}{c}\text { CFS after } \mathbf{4 8} \\
\text { hr }\end{array}$ \\
\hline $\mathbf{1 8}$ & 22 & 20 & - \\
\hline $\mathbf{5 4}$ & 18 & 16 & - \\
\hline $\mathbf{5 5}$ & 10 & 9 & - \\
\hline
\end{tabular}

*included well size of 5mm diameter; CFB: Cell Free Broth 
Fig.1 Screening of antibacterial activity of brevicin against S. aureus MCCB 0139

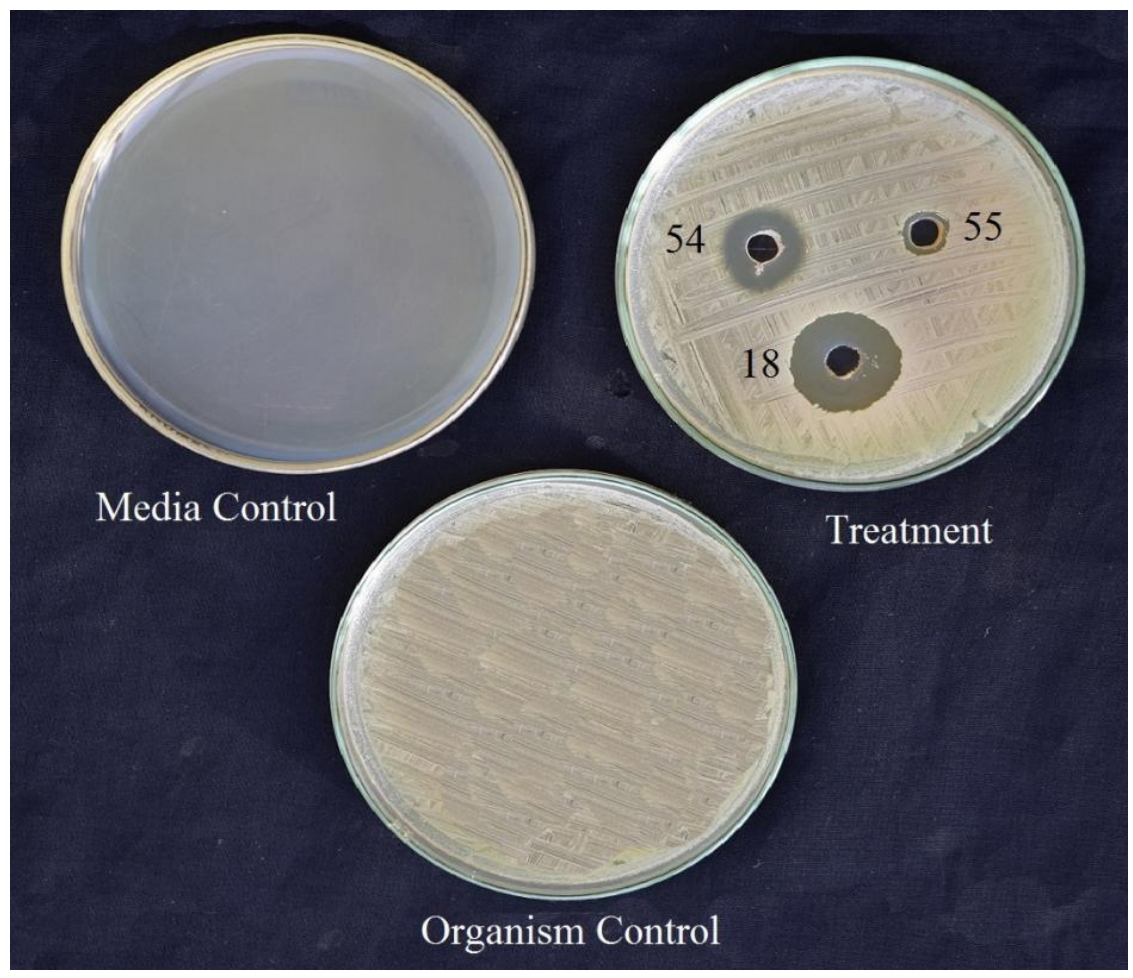

Fig.2 Screening of antibacterial activity of brevicin against E. coli MCCB 0017

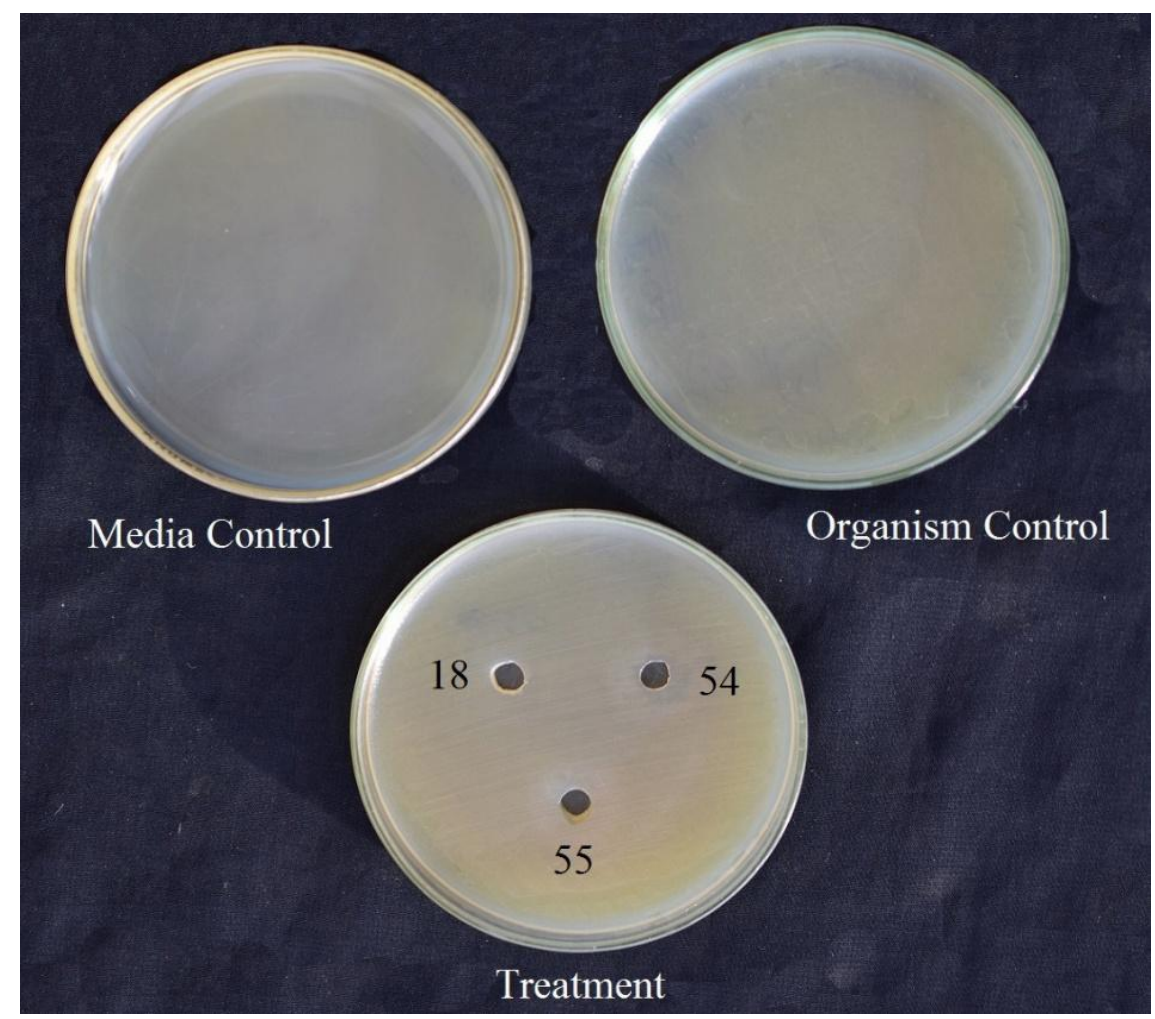


But isolates of Brevibacillus sp. have also been reported from the airborne dust (Andersson et al., 1999), food packaging products of paper and board (Pirttijarvi et al., 2000), submerged rhizosphere of sea grass Vallisneria americana (wild celery) in an estuarine environment (Kurtz et al., 2003). In the present study $B$. brevis was isolated from soil samples of dairy environment with 6.12 $\%$ occurrence level. The brown or black pigmentation produced on the agar plates was due to formation of melanin as a result of presence of tyrosine in the medium (Cubo et al., 1988). Negative result for lecitinase production and hemolysis confers the organism as nonpathogenic entity (Nakamura, 1991).

Thus, from present study, it can be concluded that brevicin from $B$. brevis is having narrow spectrum of anitimicrobial activity, restricted to gram positive organisms. Similar results have been reported by (Saleem et al., 2009), (Faheem et al., 2007) and (Chalasani et al., 2015) for brevicin. This can be explained on the basis of mode of action of anitimicrobial peptides, which primarily believed to act upon the cell membrane rich in teichoic and teichuronic acids by creating pores, these anionic structures in contrast to cationic antimicrobial peptide or bacteriocin activity, increases the negative surface charge, which is not possible with Gram negative organism. Since, it has a Lipopolysaccharide (LPS) outer membrane and a very thin layer of petidoglycan lacking teichoic and teichuronic acids (Wimley, 2010; Yeaman and Yount, 2003). However, (Hyung et al., 2001) have reported bacteriocin with broad antimicrobial activity. Various species of Bacillus have also been reported for their Antimicrobial peptide (AMP) or BLIS having broad spectrum inhibitory activity (Singh et al., 2012; Ghadbane et al., 2013; Embaby et al., 2014). In the present study the antibacterial activity of crude bacteriocin from $B$. brevis was detected to be restricted for gram positive bacteria. Maximum production was observed at $24 \mathrm{hr}$ at $37{ }^{\circ} \mathrm{C}$ with medium $\mathrm{pH}$ at neutrality. Strains of Brevibacillus are potent source of bacteriocins and these peptide antimicrobials can be used as a potent therapeutic agent in pharmaceuticals as well as can also be used as food preservatives in canned or packed food and dairy products.

\section{Acknowledgements}

We thank the department of animal husbandry and dairying, for providing the access to the farm for sheep blood collection when needed. Also we are thankful to $\mathrm{Mr}$. James, $\mathrm{PhD}$. Scholar at department of animal husbandry for providing assistance while blood collection. We also declare no conflict of interest.

\section{References}

Andersson AM, Weiss N, Rainey F. and Salkinoja-Salonen MS. 1999. Dustborne bacteria in animal sheds, schools and children's day care centres. J Appl Microbiol; 86(4):622-34.

Anja M, Tompa G, Trmcic A. and Rogelj I. 2014. Bacteriocins of Lactobacillus gasseri K7 - Monitoring of gassericin K7 A and B genes expression and isolation of an active component. Process Biochem; 49: 1251-9.

Ansari A, Aman A, Siddiqui NN. and Iqbal S. 2012. Bacteriocin (BAC-IB17): Screening, isolation and production from Bacillus subtilis KIBGE IB-17. Pak J Pharm Sci; 25(1):195-201.

Appaiah KAA, Appaiah S. and Kiran KAU. 2012. Extension of shelf life of curd an Indian fermented milk by using a new isolate of Brevibacillus brevis strain as starter culture. Innov Rom Food Biotechnol; 10:48-55. 
Bhaskar N, Sudeepa ES, Rashmi HN. and Tamil SA. 2007. Partial purification and characterization of protease of Bacillus proteolyticus CFR3001 isolated from fish processing waste and its antibacterial activities. Bioresour Technol; 98(14):2758-64.

Bhuvaneswari S, Madhavan S. and Panneerselvam A. 2015. Optimization of bacteriocin production by Bacillus subtilis BMP01 isolated From Solanum trilobatum L. Int J Curr Microbiol App Sci; 4(3): 617-26.

Bizani D. and Brandelli A. 2002. Characterization of a bacteriocin produced by a newly isolated Bacillus sp. Strain 8 A. J Appl Microbiol; 93(3):512-9.

Chalasani AG, Dhanarajan G, Nema S. and Sen R. 2015. An antimicrobial metabolite from Bacillus sp. significant activity against pathogenic bacteria including Multidrug-Resistant Clinical Strains. Front Microbiol; 6: 1335.

Cubo MT, Buendia-claveria AM, Beringer JE. and Ruiz-sainz JE. 1988. Melanin production by Rhizobium strains. Appl Environ Microbiol; 54(7): 1812-7.

Edwards SG. and Seddon B. 2000. Selective medium based on tyrosine metabolism for the isolation and enumeration of Brevibacillus brevis (Bacillus brevis). Lett Appl Microbiol; 31(5):395-9.

Elo S, Maunuksela L, Salkinoja-Salonen M. and Smolander A. 2000. Humus bacteria of Norway spruce stands: plant growth promoting properties and birch, red fescue and alder colonizing capacity. FEMS Microbiol Ecol; 31(2):143-52.

Embaby AM, Heshmat Y. and Hussein A, Marey HS. 2014. A sequential statistical approach towards an optimized production of a broad spectrum bacteriocin substance from a soil bacterium Bacillus sp. YAS 1 strain Scientific World Journal; 396304.

Faheem F, Saeed S. and Rasool SA. 2007. Studies on brevicin AF01: a bacteriocin like inhibitory substance active against methicillin resistant Staphylococcus aureus. Pak J Bot; 39(4): 1293-302.

Food safety strategic planning meeting: report of a WHO strategic planning meeting, WHO headquarters, Geneva, Switzerland, 20-22 February 2001 (http://whqlibdoc.who.int/hq/2001/WH O_SDE_PHE_FOS_01.2.pdf). World Health Organization, Geneva.

Galvez A, Abriouel H, Lopez RL. and Omar BN. 2007. Bacteriocin-based strategies for food biopreservation. Int $\mathrm{J}$ Food Microbiol; 120(1-2), 51-70.

Ghadbane M, Harzallah D, Labribi AI. and Jaouadi B. 2013. Purification and biochemical characterization of highly thermostable bacteriocin isolated from Brevibacillus brevis strain GM 100. Biosci Biotechnol Biochem; 77 (1): 151-160.

Gillor O, Etzion A. and Riley MA. 2008. The dual role of bacteriocins as anti- and probiotics. Appl Microbiol Biotechnol; 81(4):591-606.

Hyung MJ, Kwang-Soo K, Jong-Hyun P. and Myung-Woo B. 2001. Bacteriocin with a broad antimicrobial spectrum, produced by Bacillus sp. isolated from Kimchi. J Microbiol Biotechnol; 11(4): 577-584.

Klaenhammer TR. 1988. Bacteriocins of lactic acid bacteria. Biochimie; 70: 33749.

Klaenhammer TR. 1993. Genetics of bacteriocins produced by lactic acid bacteria. FEMS Microbiol Rev; 12(1-3): 39-85.

Kurtz JC, Yates DF, Macauley JM. and Qurles RL. 2003. Effects of light reduction on growth of the submerged macrophyte Vallisneria americana and 
the community of root associated heterotrophic bacteria. J Exp Mar Bio Ecol; 291: 199-218.

Maisnier-Patin S, Deschamps N, R Tatini S. and Richard J. 1992. Inhibition of Listeria monocytogenes in Camembert cheese made with a nisin-producing starter. Lait; 72: 249-63.

Nakamura LK. 1991. Bacillus brevis Migula 1900 Taxonomy: Reassociation and base Composition of DNA. Int J Syst Bacteriol; 41(4):510-5.

Pattnaik P, Grover S. and Batish VK. 2005. Effect of environmental factors on production of lichenin, a chromosomally encoded bacteriocinlike compound produced by Bacillus licheniformis 26L-10/3RA. Microbiol Res; 160(2): 213-8.

Pirttijarvi TS, Andersson MA. and SalkinojaSalonen MS. 2000. Properties of Bacillus cereus and other bacilli contaminating biomaterial- based industrial processes. Int $\mathbf{J}$ Food Microbiol; 60(2-3): 231-9.

Saleem F, Ahmad S, Yaqoob Z. and Rasool SA. 2009. Comparative study of two bacteriocins produced by representative indigenous soil bacteria. Pak J Pharm Sci; 22(3): 252-8.

Shida O, Takagi H, Kadowaki LK. and Komagata K. 1996. Proposal for two new genera, Brevibacillus gen. Nov. and Aneurinibacillus gen. Nov. Int J Syst Bacteriol; 939-46.

Singh PK, Chittpurna, Ashish SV. and Patil PB. 2012. Identification, purification and characterization of Laterosporulin, a novel bacteriocin produced by Brevibacillus sp. Strain GI-9. Plos One; 7(3): e31498.

Vos P, Garrity G, Jones D. and Krieg NR. (Eds) 2009. Genus Brevibacillus, pp. 305-316. Bergey's Manual of Systematic Bacteriology, 2nd ed. vol. 3, The Firmicutes. Dordrecht; Springer 2009; New York, USA.

Wimley WC. 2010. Describing the mechanism of antimicrobial peptide action with the interfacial activity model. ACS Chem Biol; 5(10): 905-17.

Yeaman MR. and Yount NY. 2003. Mechanisms of antimicrobial peptide action and resistance. Pharmacol Rev; 55(1): 27-55.

\section{How to cite this article:}

Sandeep Kumar, Ebenezer Jeyakymar, Rubina Lawrence, Utkarsh Singh Rathore and Monika Mishra 2018. Screening of Antimicrobial Spectrum of Brevibacillus sp. Isolated from Dairy Environment. Int.J.Curr.Microbiol.App.Sci. 7(05): 850-858. doi: https://doi.org/10.20546/ijcmas.2018.705.104 